\title{
PENERAPAN MEDIA KOMIK PADA PEMBELAJARAN BIPA (Studi Kasus pada Peserta Korea Tingkat Pemula di Universitas Trisakti Jakarta)
}

\author{
Randi Ramliyana \\ Program Studi Teknik Informatika, Universitas Indraprasta PGRI \\ Email: randi.ramliyana@gmail.com
}

\begin{abstract}
Abstrak
Penelitian ini bertujuan untuk mendeskripsikan penerapan media komik pada pembelajaran Bahasa Indonesia bagi Penutur Asing (BIPA) di Pusat Bahasa Universitas Trisakti Jakarta. Salah satu masalah terbesar yang dihadapi dalam pembelajaran BIPA ialah motivasi belajar peserta. Ada banyak alasan peserta kurang termotivasi dalam belajar BIPA, salah satunya ialah suasana kelas yang membosankan. Satu hal yang kita ketahui untuk membangkitkan motivasi belajar peserta ialah dengan memberikan suatu hal yang luar biasa dan baru di dalam pembelajaran BIPA, terutama di antara peserta usia remaja dan dewasa awal. Penelitian ini menggunakan metode penelitian kualitatif deskriptif dengan menggunakan pendekatan studi kasus. Hasil dari penelitian ini mengatakan bahwa komik dapat digunakan secara efisien untuk mencapai tujuan pembelajaran tersebut. Media komik mampu menyampaikan mata kuliah menyimak, berbicara, membaca, dan tata bahasa dalam pembelajaran BIPA. Hal tersebut memberikan atmosfer yang menyenangkan di dalam kelas. Komik tidak hanya menghibur dan menarik peserta, tetapi juga ada banyak alasan menggunakannya di dalam pembelajaran BIPA.
\end{abstract}

Kata Kunci: Komik, Media, BIPA

\section{Pendahuluan}

Program Bahasa Indonesia bagi Penutur Asing (BIPA) adalah sebuah program pembelajaran bahasa Indonesia sebagai bahasa kedua bagi penutur asing. Pada pembelajaran BIPA, peserta akan belajar mengenai empat keterampilan berbahasa, yaitu menyimak, berbicara, membaca, dan menulis. Keempat keterampilan tersebut saling terkait satu dengan yang lainnya. Dalam pembelajaran BIPA, peserta dituntut untuk menguasai semua keterampilan berbahasa. Pembelajaran BIPA tidak seperti pembelajaran bahasa Indonesia bagi penutur asli. Peserta dituntut mampu menguasai bahasa Indonesia dalam waktu yang ditentukan. Oleh karena itu, pengajar bertugas menyediakan aktivitas dan menciptakan suasana menyenangkan selama proses pembelajaran BIPA. Banyak cara menciptakan suasana yang menyenangkan ke dalam proses pembelajaran BIPA. Salah satunya ialah dengan menggunakan media pembelajaran yang disukai anak-anak, yaitu komik. Anak-anak menyukai komik karena sangat menyenangkan untuk dibaca. Selain anak-anak, orang dewasa pun menyukainya karena komik juga memberikan beragam informasi di dalamnya. Oleh karena itu, komik dapat menjadi media pembelajaran yang efektif.

Komik sebagai media pembelajaran sudah lama diterapkan dan memberikan dampak yang positif selama proses pembelajaran. Media komik selain menyenangkan, juga selalu dikaitkan dapat meningkatkan minat membaca, serta mengembangkan perbendaharaan kosakata dalam berbahasa. Komik digunakan sebagai langkah awal untuk membangkitkan minat membaca peserta, terutama yang tidak suka membaca. Selain karena komik menghibur, menyenangkan, dan edukatif, komik juga merupakan jembatan untuk membaca buku yang lebih serius. Jadi, dapat disimpulkan bahwa media komik memiliki kaitan yang erat dengan pembelajaran bahasa karena selalu dikaitkan dengan peningkatan keterampilan berbahasa. Oleh karena itu, jika membicarakan tentang media komik yang berpengaruh 
penting dalam peningkatan minat membaca peserta, secara otomatis kemampuan peserta dalam menulis pun akan meningkat.

Oleh sebab itu, penelitian ini bertujuan untuk mendeskripsikan penerapan media komik pada pembelajaran Bahasa Indonesia bagi Penutur Asing (BIPA) di Pusat Bahasa Universitas Trisakti Jakarta. Peneliti berharap penelitian ini akan berguna bagi dunia pendidikan bahasa, terutama BIPA, di Indonesia dan memberikan solusi baru dengan menggunakan komik sebagai media pembelajaran yang menyenangkan dan tepat bagi semua peserta.

\section{Tinjauan Pustaka}

\section{Media Pembelajaran}

Media berasal dari bahasa Latin yang merupakan bentuk jamak dari medium yang berarti perantara atau pengantar, yaitu perantara atau pengantar sumber pesan dengan penerima pesan. Media pembelajaran interaktif adalah sebuah metode pembelajaran berbasis teknologi informasi dan komunikasi. Media pembelajaran interaktif merupakan media penyampaian pesan antara pengajar dan peserta yang memungkinkan komunikasi antara manusia dan teknologi melalui sistem dan infrastruktur berupa program aplikasi serta pemanfaatan media elektronik sebagai bagian dari metode edukasinya. Media pembelajaran dewasa ini sudah merupakan kewajiban yang harus disiapkan oleh para pengajar dalam upaya menciptakan suasana pembelajaran yang menarik, menyenangkan, menggairahkan, dan menggugah. Dengan menggunakan media pembelajaran, interaksi antara pengajar dan peserta akan lebih efektif karena mereka bisa berkomunikasi satu sama lain dan yang terpenting, mampu berperan secara aktif memanfaatkan media pembelajaran dalam setiap kegiatan belajarmengajar.

Media pembelajaran sebaiknya diciptakan sesuai dengan kebutuhan peserta. Kesempurnaan media pembelajaran akan tercipta apabila pengajar mampu membuat dalam bentuk manual dan dalam bentuk elektronik. Media pembelajaran manual dapat dibuat mulai dari bahan yang sederhana hingga bahan yang rumit. Hal tersebut bergantung pada kemampuan pengajar untuk menyiapkan bahan dan mengemasnya secara baik. Hal tersebut sejalan dengan apa yang dikatakann oleh Edgar Dale, "Penggunaan media pembelajaran seringkali menggunakan prinsip Kerucut Pengalaman yang membutuhkan media, seperti buku teks, bahan belajar yang dibuat oleh guru, dan audio-visual."

\section{Komik}

Peneliti memilih komik sebagai media pada pembelajaran BIPA karena komik merupakan media yang menyenangkan dan dapat menjadi media edukatif selama proses pembelajaran berlangsung. Namun, masyarakat masih beranggapan bahwa komik hanya cerita bergambar yang ringan dan menyenangkan. Banyak orang yang belum tahu definisi tentang komik. Oleh sebab itu, banyak yang telah mencoba mengemukakan definisi komik, di antaranya adalah sebagai berikut.

Menurut (McCloud, 2001), komik adalah gambar-gambar dan lambang-lambang lain yang terjuktaposisi dalam tuturan tertentu, bertujuan untuk memberikan informasi dan mencapai tanggapan estetis dari pembaca. Harvey dalam (McCloud, 2008) menyarankan pernyataan kombinasi berseni dari kata dan gambar harus terliput dalam semua definisi tentang komik. McCloud menambahkan tentang kekuatan kata adalah bagian tak terpisahkan dari pesona karya seni yang disebut komik. (Sudjana dan Rivai, 2001) berpendapat komik dapat didefinisikan sebagai suatu bentuk kartun yang mengungkapkan karakter dan memerankan suatu cerita dalam urutan yang erat dihubungkan dengan gambar dan dirancang untuk memberikan hiburan kepada para pembaca. (Masdiono, 2001) mengatakan komik adalah 
gamcer atau gambar bercerita atau sebuah dunia tutur gambar, suatu rentetan gambar yang bertutur menceritakan suatu kisah. Dalam Kamus Umum Bahasa Indonesia (KBBI), komik adalah bacaan bergambar, cerita bergambar (dalam majalah, surat kabar, atau berbentuk buku).

(Eisner , 2002) mendefinisikan teknis dan struktur komik sebagai sequential art susunan gambar dan kata-kata untuk menceritakan sesuatu atau mendramatisasi suatu ide. Para ahli masih belum sependapat mengenai definisi komik, sebagian di antaranya berpendapat bahwa bentuk cetaknya perlu ditekankan, yang lain lebih mementingkan kesinambungan gambar dan kata, dan sebagian lain lebih menekankan sifat kesinambungannya (sequential).

Berdasarkan beberapa definisi tentang komik di atas, peneliti menyimpulkan bahwa komik adalah salah satu karya sastra bernilai estetis yang terdiri atas perpaduan antara gambar dan kata yang membentuk sebuah cerita. Selain itu, bertujuan untuk memberikan informasi dan hiburan kepada pembaca.

Daya tarik berbagai jenis komik mengikuti pola yang dapat diprediksikan. (Hurlock, 2000) berpendapat bahwa anak-anak usia sekolah menyukai komik karena beberapa hal di antaranya:

1. melalui identifikasi dengan karakter di dalam komik, anak memperoleh kesempatan yang baik untuk mendapat wawasan mengenal masalah pribadi dan sosialnya. Hal ini akan membantu memecahkan masalahnya,

2. komik menarik imajinasi anak dan rasa ingin tahu tentang masalah supranatural,

3. komik memberi anak pelarian sementara hirup-pikuk hidup sehari-hari,

4. komik mudah dibaca, bahkan anak yang kurang mampu membaca dapat memahami arti dari gambarnya,

5. karena komik tidak mahal dan juga ditayangkan di televisi sehingga semua anak mengenalnya,

6. karena banyak komik yang menggairahkan, misterius, dan lucu, komik mendorong anak untuk membaca yang tidak banyak diberikan buku lain,

7. bila berbentuk serial, komik memberi sesuatu yang diharapkan,

8. dalam komik, tokoh sering melakukan atau mengatakan hal-hal yang tidak berani mereka lakukan sendiri, walaupun mereka ingin melakukannya, ini memberikan kegembiraan,

9. tokoh dalam komik sering kuat, berani, dan berwajah tampan, jadi memberikan tokoh pahlawan bagi anak untuk mengidentifikasikannya,

10. gambar dalam komik berwarna-warni dan cukup sederhana untuk dimengerti anak-anak.

Menurut Oller dan teori peristiwa miliknya (1983) teks (bentuk ujaran dan tulis dalam wacana) yang lebih tidak sengaja tersusun dapat disimpan dan diingat kembali lebih mudah daripada bahan yang kurang tersusun secara tidak sengaja. Dengan kata lain, hal itu lebih mudah bagi peserta belajar bahasa jika mereka diberikan kalimat terhubung yang memiliki struktur logis dan alur cerita, bukannya terputus, frase diatur secara acak. Kosakata dan bahasa dapat dipelajari dalam konteks. Namun, Oller selangkah lebih maju dan menyatakan bahwa konteks itu sendiri tidak cukup. Hal yang terpenting adalah dialog atau teks harus memiliki struktur logis dan simpulan yang logis. Dengan cara ini, peserta dapat mengikuti alur cerita selangkah demi selangkah dan dapat mengingat struktur lebih mudah karena logika membantu mereka.

Teori Oller dapat diterapkan pada penggunaan komik dalam pengajaran bahasa. Komik memiliki alur cerita yang mampu membawa peserta pada simpulan dari materi yang dibawakan. Dengan cara itu, peserta termotivasi melanjutkan untuk membaca dan kembali lebih terlibat ke dalam isi daripada bahasa. Konsekuensinya, peserta akan lebih asyik mengetahui apa yang akan terjadi, bagaimana akhir dari cerita (rasa pensaran mereka muncul), dan akan mengingat bentuk kata, ekspresi, dan gramatikal lebih mudah. Komik juga dapat digunakan sebagai fasilitas pengajaran kosakata. 
(Brown, 1994) menunjukkan bahwa internalisasi terbaik dari kosakata berasal dari pertemuan (komprehensi dan produksi) kata dalam konteks sekitarnya. Dengan cara ini, peserta akan mengasosiasikan kata dengan konteks sebenarnya dan mereka dapat mengingat dan menggunakannya lebih baik daripada hanya mempelajari setah kata dan maknanya secara korespondensinya. Selain kosakata, kompetensi tata bahasa dapat ditingkatkan dengan baik. Dengan bantuan komik, tata bahasa baru dapat diperkenalkan dan dipraktikan, dan sejak materi tata bahasa ditanamkan di dalam cerita dengan struktur yang logis, peserta akan mampu mengingat lebih baik selanjutnya.

Karakteristik komik juga mampu meningkatkan motivasi (khususnya komik yang berwarna). Hal yang lebih penting jika kata, ekspresi, atau konsep disertai oleh gambar (visual gambar dalam satu pikiran), selanjutnya peserta akan lebih mudah menghafal dan mengingat lebih mudah. Fakta bahwa visual komik juga berkontribusi untuk meningkatkan kompetensi komunikasi. Di dalam komik, kehidupan seperti situasi dan ekspresi yang digunakan dalam percakapan, bahasa sehari-hari, sebagai contoh, idiom, pengurangan bentuk, bahasa slang, dan ekspresi yang membutuhkan berbagai pengetahuan budaya. Konsekuensinya, komik membantu peserta menangani percakapan bahkan dalam situasi informal. Keuntungan lainnya dari visual komik adalah gestur dan bahasa tubuh dari para tokoh. Kontribusi ini untuk membangun kompetensi komunikasi, yang artinya termasuk ke dalam komunikasi nonverbal.

\section{Metodologi Penelitian}

Penelitian ini berbentuk penelitian kualitatif dengan pendekatan studi kasus. Subjek penelitian ini adalah peserta Program Bahasa Indonesia bagi Penutur Asing (BIPA) Universitas Trisakti Jakarta tingkat pemula. Objek penelitian adalah penerapan media komik dalam pembelajaran BIPA. Sumber data untuk mengetahui perencanaan pembelajaran BIPA adalah pengajar BIPA pada tingkat pemula dan dokumen lesson plan yang disusun pengajar, sedangkan untuk proses pembelajaran dan penilaian hasil belajar adalah proses/kegiatan pembelajaran BIPA pada tingkat pemula.

Pengumpulan data dilakukan dengan wawancara mendalam, pengamatan, dan studi dokumentasi. Wawancara dan pengamatan dilakukan untuk memperoleh informasi yang nyata berkaitan dengan kegiatan pengajar dalam merencanakan, melaksanakan, dan menilai hasil belajar BIPA. Kegiatan studi dokumentasi dilakukan untuk mempelajari dokumen yang dimiliki oleh pengajar, yang berupa catatan materi, silabus dan lesson plan BIPA. Keabsahan data diperoleh dengan dua cara, yaitu pengamatan secara terus menerus dan triangulasi. Teknik triangulasi yang dilakukan, yaitu triangulasi sumber data. Triangulasi sumber data digunakan untuk mengumpulkan informasi dari pengajar BIPA dan peserta BIPA pada tingkat pemula. Selanjutnya, peneliti melakukan pengecekan, pengecekan ulang, dan pengecekan silang. Data dalam penelitian ini dianalisis dengan cara analisis kualitatif, yaitu cara interaktif yang terdiri atas tiga tahap analisis, yaitu: reduksi data, pemaparan data/penyajian data, dan penyimpulan. Kegiatan pereduksian data ini dilaksanakan secara langsung dan terus menerus. Penyajian data disampaikan secara naratif dan terpilah. Penyimpulan dilakukan berdasarkan analisis dan hasil diskusi antara peneliti dan pengajar.

\section{Hasil dan Pembahasan}

Perencanaan Pembelajaran BIPA di Pusat Bahasa Universitas Trisakti Jakarta

Pengajar yang mengajar di kelas BIPA pada tingkat pemula harus menyiapkan dan menyusun lesson plan sebelum melaksanakan pembelajaran di dalam kelas. Lesson plan untuk setiap mata kuliah BIPA dibuat setiap pertemuan. Hal ini diketahui berdasarkan hasil wawancara dengan pengajar BIPA pada tingkat pemula. Lesson plan disusun untuk setiap 
kompetensi dasar. Isi lesson plan tersebut terdiri dari beberapa komponen, yaitu identitas, standar kompetensi, kompetensi dasar, indikator, tujuan pembelajaran, materi, metode, langkah-langkah pembelajaran, alat dan sumber belajar, serta penilaian.

Penyusunan rencana pembelajaran secara umum perlu memperhatikan beberapa hal. Dalam merencanakan pembelajaran, pengajar harus mengatur, mengoordinasikan, dan menetapkan unsur-unsur atau komponen-komponen pembelajaran yang berupa tujuan pembelajaran (kompetensi), isi atau materi yang harus diberikan untuk mencapai kompetensi, strategi pelaksanaan, dan penilaian yang digunakan untuk mengukur tingkat keberhasilan pembelajaran. Komponen tersebut tidaklah berdiri sendiri, tetapi saling berinteraksi, saling mempengaruhi sehingga membentuk satu kesatuan. Penyusunan lesson plan oleh pengajar BIPA pada tingkat pemula dilakukan dengan mengetik di komputer.

\section{Perencanaan Tujuan Pembelajaran}

Tujuan pembelajaran BIPA adalah agar peserta terampil menggunakan bahasa Indonesia secara komunikatif dan pragmatis (Badan Bahasa, 2012). Tujuan umum tersebut diterjemahkan pengajar melalui kompetensi dasar yang dijabarkan menjadi indikatorindikator pada setiap pertemuan. Selanjutnya, pengajar merumuskan tujuan pembelajaran tiap pertemuan berdasarkan indikator tersebut. Sebelum mengajar BIPA, pengajar BIPA pada tingkat pemula telah merencanakan tujuan pembelajaran yang akan dicapai pada hari itu yang dituliskan dalam lessson plan. Perencanaan tujuan pembelajaran tersebut merupakan target atau hasil yang akan dicapai. Keberadaan target tersebut akan mengawal arah pembelajaran sehingga dalam proses pembelajaran yang dilaksanakan tidak menyimpang.

Berdasarkan tujuan yang tertulis dalam lesson plan, tampak bahwa pengajar BIPA di Program BIPA Universitas Trisakti Jakarta tidak hanya menekankan pada aspek kebahasaannya, tetapi juga pada aspek kebudayaannya. Hal ini sesuai dengan tujuan pembelajaran BIPA yang dirumuskan oleh Badan Bahasa.

\section{Penentuan Materi dan Pemilihan Strategi Pembelajaran}

Penentuan materi dan pemilihan strategi pembelajaran merupakan dua aspek yang tidak dapat dipisahkan satu sama lain dalam proses pembelajaran. Materi pembelajaran harus diajarkan dan dipelajari peserta sebagai sarana pencapaian standar kompetensi dan kompetensi dasar yang akan dinilai dengan menggunakan instrumen penilaian yang disusun berdasarkan indikator pencapaian hasil belajar. Berkaitan dengan hal tersebut, penyampaian informasi untuk mencapai kompetensi erat kaitannya dengan strategi pembelajaran yang dipilih. Banyak strategi belajar yang dapat digunakan dalam proses belajar di kelas BIPA.

Pengajar BIPA pada tingkat pemula telah merencanakan pemilihan strategi atau metode mengajar sebelum proses pembelajaran BIPA dilaksanakan. Metode yang direncanakan pengajar ialah metode pembelajaran kooperatif yang menggunakan model pembelajaran picture and picture. Metode pembelajaran kooperatif merupakan suatu model pembelajaran yang mengutamakan adanya kelompok-kelompok. Pembelajaran kooperatif adalah pembelajaran yang secara sadar dan sistematis mengembangkan interaksi yang saling asah, silih asih, dan silih asuh. Model pembelajaran picture and picture adalah suatu metode belajar yang menggunakan gambar yang diurutkan secara logis. Pembelajaran ini memiliki ciri aktif, inovatif, kreatif, dan menyenangkan. Model apapun yang digunakan selalu menekankan aktifnya peserta didik dalam setiap proses pembelajaran. Model pembelajaran ini mengandalkan gambar sebagai media dalam proses pembelajaran. Gambar-gambar ini menjadi faktor utama dalam proses pembelajaran, salah satunya adalah media komik.

\section{Perencanaan Penilaian}


Penilaian hasil belajar perlu dilakukan untuk mengetahui perkembangan dan kemajuan belajar peserta. Dalam lesson plan yang disusun pengajar, juga dituliskan rencana penilaian yang akan dilakukan. Penilaian dilakukan secara tertulis dan lisan. Penilaian tertulis dilakukan dalam bentuk mengisi kalimat rumpang, sedangkan penilaian lisan dilakukan dalam bentuk berbicara. Penilaian direncanakan dilakukan pada setiap akhir kegiatan pembelajaran. Jadi, jika satu kompetensi dasar disampaikan dalam dua kali tatap muka, penilaian pun dilakukan guru sebanyak dua kali.

\section{Pelaksanaan Pembelajaran BIPA di Pusat Bahasa Universitas Trisakti Jakarta}

Pembelajaran BIPA pada tingkat pemula dilaksanakan dari Senin hingga Kamis. Dalam seminggu,para peserta mendapatkan waktu selama 16 jam dalam belajar BIPA. Pada hari Senin dan Rabu, peserta akan mempelajari mata kuliah berbicara dan menyimak. Sementara pada Selasa dan Kamis, peserta akan mempelajari mata kuliah membaca dan tata bahasa. Mereka belajar setiap harinya dari pukul 09.00 sampai dengan pukul 12.30 WIB. Berdasarkan pengamatan pada hari Senin, 11 Januari 2016, dan Selasa, 12 Januari 2016, proses pelaksanaan pembelajaran BIPA pada tingkat pemula diuraikan berikut ini.

\section{Kegiatan guru dalam mengawali pembelajaran}

Pembelajaran BIPA pada tingkat pemula sesuai dengan jadwal pembelajaran yang sudah dituliskan di atas, dilaksanakan dari Senin hingga Kamis dari pukul 09.00 s.d. 12.30 WIB. Sebelum membuka pelajaran pengajar menyapa dan memperkenalkan diri kepada peserta terlebih dahulu. Seperti biasa, pengajar langsung membuka pembelajaran dengan mengucapkan salam, "Selamat Pagi!" Salam tersebut kemudian dijawab dengan antusias oleh para peserta BIPA "Selamat Pagi, Pak!"Pengajar kemudian menanyakan kabar kepada peserta, "Apa kabarnya?" Sebagian peserta akan menjawab dan sebagian lagi mencoba untuk menjawab meskipun malu. Hari ini adalah hari pertama pada semester awal Program BIPA di Pusat Bahasa Universitas Trisakti Jakarta. Para peserta semua berasal dari Korea Selatan. Jumlah peserta di kelas pemula ini adalah lima orang. Mereka memiliki latar belakang yang berbeda dan pengalaman berbeda dengan bahasa Indonesia. Setelah menyapa dan menanyakan kabar, pengajar kemudian memperkenalkan diri dalam bahasa Indonesia, "Kenalkan nama saya Bari Pratama." Pengajar lalu mengecek presensi peserta BIPA dan mencoba mengenal lebih dekat dengan para peserta.

Pengajar memanggil nama mereka dan mencoba berinteraksi dalam bahasa Indonesia. Hal tersebut bertujuan untuk mengukur sejauh mana keterampilan mereka berbahasa Indonesia. Setelah mengenal latar belakang para peserta, pengajar mulai menyampaikan tujuan pembelajaran hari itu. Pada saat observasi tanggal 11 Januari 2016 dan 12 Januari 2016, para peserta BIPA pada tingkat pemula sedangmempelajari bahasa Indonesia dengan kompetensi dasar "Mengenal huruf" Berdasarkan lesson plan, tujuan pembelajaran mata kuliah berbicara dan menyimak yang dilaksanakan pada Senin tanggal 11 Januari 2016 adalahmelalui metode picture and picture dengan komik, peserta dapat menyebutkan huruf dalam bahasa Indonesia dan memperkenalkan diri mereka dalam bahasa Indonesia.

Pada tanggal 12 Januari 2016, para peserta BIPA akan mempelajari mata kuliah membaca dan tata bahasa. Kompetensi dasarnya sudah berganti, yaitu "Mengenal pronomina bahasa Indonesia" Tujuan pembelajarannya adalah peserta dapat menggunakan kata pronomina orang pertama, kedua, dan ketiga dengan baik. Uraian kegiatan awal dalam pembelajaran BIPA yang dilakukan pengajar tersebut sesuai dengan pendapat (Darmadi, 2009), "Bahwa kegiatan awal pembelajaran dilaksanakan untuk membangkitkan motivasi dan perhatian peserta didik dalam mengikuti pembelajaran, memberikan gambaran yang jelas tentang batas-batas tugas atau kegiatan yang akan dilaksanakan, dan menunjukkan hubungan antara pengalaman peserta dengan materi yang akan dipelajari." 


\section{Kegiatan guru dalam penerapan media komik pada pembelajaran BIPA}

Pengajar melanjutkan kegiatan belajar mengajar sesuai dengan materi yang akan dipelajari, yaitu tentang mengenal huruf dan memperkenalkan diri. Media yang digunakan untuk materi ini adalah komik. Komik ini digunakan untuk membantu peserta menyimak kosakata yang mereka dengar dari rekaman. Di dalam komik, balon kata yang kosong dapat mereka isi sesuai dengan kata-kata yang mereka dengar dari rekaman. Namun, sebelum memulainya, pengajar harus mengajarkan terlebih dahulu huruf-huruf dalam bahasa Indonesia dan mengucapkannya bersama-sama dengan para peserta.

Pada Senin, 11 Januari 2016, pengajar harus mengajarkan peserta membaca huruf dikarenakan seluruh peserta berasal dari Korea Selatan. Mereka tidak menggunakan tulisan Latin dalam tulisan mereka, tetapi menggunakan tulisan Hangeul (aksara dalam bahasa Korea Selatan). Para peserta pun tidak mahir dalam berbahasa Inggris dengan baik. Oleh karen itu, penting sekali pengajar memulai dengan pengenalan huruf-huruf bahasa Indonesia. Setelah peserta selesai belajar mengenai huruf-huruf, pada mata kuliah menyimak dan berbicara, Peserta diharuskan mengisi setiap balon kata yang kosong tersebut. Adapun tampilan dari komik tersebut adalah sebagai berikut.
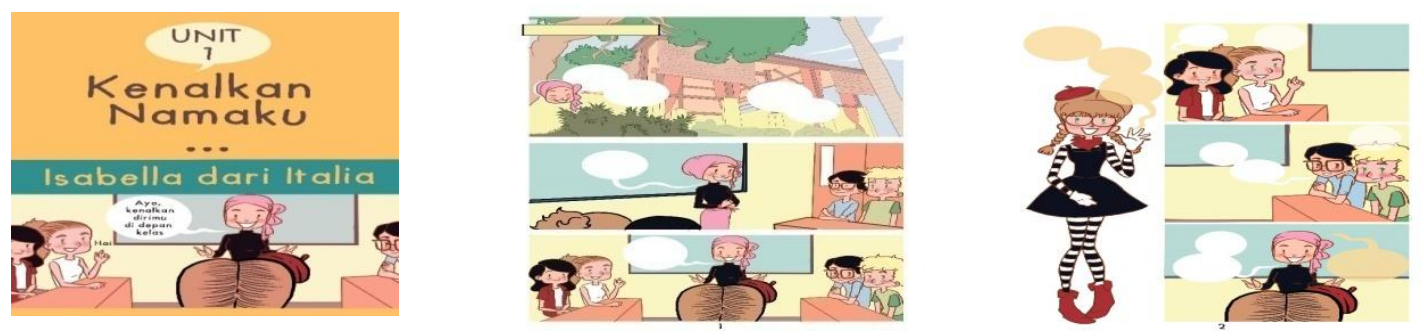

Gambar 1. Komik Mata Kuliah Menyimak dan Berbicara

Pengajar akan membagikan komik tersebut. Setelah mendapatkan komiknya, peserta akan melihat-lihat komiknya dan bersiap untuk mendengarkan rekaman yang akan diputar pengajar.

\section{Aktivitas 1}

Pengajar akan memutar rekaman yang berisi dialog di dalam komik. Kecepatan rekaman disesuaikan dengan kemampuan para peserta di tingkat pemula, yaitu tidak terlalu cepat.

\section{Aktivitas 2}

Peserta mulai mengisi balon kata dengan yang mereka dengar dari rekaman. Biasanya pada rekaman pertama, peserta belum mampu mengisi dengan lengkap balon kata yang ada di komik tersebut. Oleh karena itu, pengajar harus mengulang 2-3 kali lagi.

\section{Aktivitas 3}

Pada aktivitas 3, pengajar dan peserta akan membahas apa isi balon kata yang kosong tersebut. Setiap peserta mendapat giliran untuk menjawab setiap balon kata yang ada.

\section{Aktivitas 4}

Peserta kemudian melakukan simulasi berperan dalam kelompok. Dalam hal ini, peserta akan mengikuti apa yang sudah mereka pelajari di kelas menyimak sebelumnya. Mereka akan mengikuti balon kata yang ada di komik.

Pada Selasa, 12 Januari 2016, peserta akan mempelajari mata kuliah membaca dan tata bahasa menggunakan media komik juga. Penggunaan media komik ini saling terkait dan 
terintegrasi satu dengan lainnya. Sebelum membaca teks bahas Indonesia yang serius, peserta dapat menggunakan komik sebagai jembatan dalam membaca.
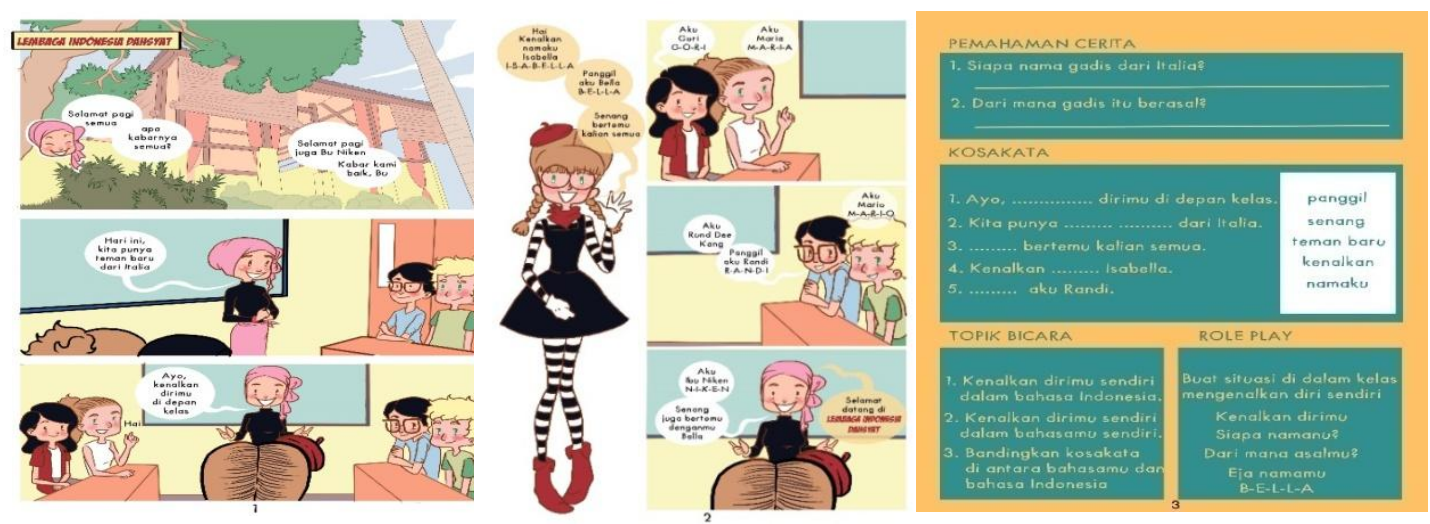

Gambar 2. Komik Mata Kuliah Membaca dan Tata Bahasa

Pengajar akan meminta peserta untuk membuka kembali komik yang kemarin sudah diterima mereka. Peserta akan akan diminta untuk membaca setiap kata dan kalimat yang ada di dalam balon kata komik tersebut. Pembelajaran ini akan menyenangkan bagi para peserta yang baru pertama kali belajar bahasa Indonesia. Setelah membaca, peserta akan mengerjakan soal yang berkaitan dengan tata bahasa yang ada di dalam komik tersebut. Adapun langkah-langkah dari penerapan komik pada mata kuliah membaca dan tata bahasa adalah sebagai berikut.

\title{
Aktivitas 1
}

Pengajar akan membagi peran setiap peserta sesuai dengan tokoh yang ada di dalam komik. Pengajar akan mengulangi instruksi hingga peserta memahami apa yang harus dilakukan mereka.

\begin{abstract}
Aktivitas 2
Setelah memahami instruksi, peserta dapat membaca setiap dialog bagian mereka masingmasing. Aktivitas ini dapat dilakukan berulang-ulang hingga peserta terbiasa dengan katakata dan kalimat di dalamnya. Agar tidak membosankan, pengajar dapat membuat peserta berganti peran di dalam komik.
\end{abstract}

\section{Aktivitas 3}

Selesai dari aktivitas 2, pengajar dapat menanyakan atau menjelaskan kosakata yang tidak dipahami.

\footnotetext{
Aktivitas 4

Pada aktivitas ini, pengajar dapat menjelaskan mengenai budaya memperkenalkan diri di depan kelas merupakan suatu budaya yang melekat di Indonesia, speerti kata pepatah, "Tak kenal, maka tak sayang".
}

\begin{abstract}
Aktivitas 5
Pada aktivitas 5, pengajar sudah yakin bahwa kosakata yang ada di dalam komik sudah dipahami mereka. Pengajar akan mulai memberikan latihan tata bahasa yang ada di akhir buku komik. Pengajar akan membimbing peserta ketika menjawab pertanyaan yang ada di akhir buku komik.
\end{abstract}

\section{Kegiatan Guru dalam Mengakhiri Pembelajaran}

Di akhir pembelajaran, pengajar tidak lupa menyimpulkan pembelajaran, memberikan evaluasi, dan budaya kepada para peserta BIPA. Pengajar kemudian menutup pembelajaran 
dengan menyampaikan salam. Pengajar juga akan menuliskan laporan harian pembelajaran di kelas.

\section{Penilaian Hasil Belajar BIPA di Pusat Bahasa Universitas Trisakti Jakarta}

Cara yang dilakukan oleh pengajar untuk mengetahui kemampuan peserta dalam penguasaan materi adalah melalui penilaian. Kriteria penilaian yang dilakukan pengajar ialah aspek keterampilan dan pemahaman. Hal ini tampak dari teknik yang digunakan berupa tes dan instrumennya berupa soal serta praktik. Hasil belajar peserta pada hakikatnya adalah perubahan tingkah laku. Tingkah laku sebagai hasil belajar dalam pengertian yang luas mencakup aspek kognitif, afektif, dan psikomotor. Salah satu fungsi penilaian menurut (Sudjana, 2006) adalah sebagai alat untuk mengetahui tercapai tidaknya tujuan pembelajaran. Dengan fungsi ini, penilaian harus mengacu pada rumusan-rumusan tujuan pembelajaran sebagai penjabaran dari kompetensi mata kuliah. Berdasarkan hasil pengamatan dan lesson plan, pengajar hanya melakukan penilaian hasil belajar pada aspek keterampilan dan pemahaman saja. Hal tersebut nampak dari instrumen penilaian.

\section{Simpulan dan Saran}

Berdasarkan hasil penelitian yang telah dilakukan di Pusat Bahasa Universitas Trisakti Jakarta, dapat disimpulkan sebagai berikut.

1. Cara pengajar BIPA dalam merencanakan program pembelajaran adalah dengan menyiapkan materi pelajaran untuk tiap-tiap pertemuan sesuai dengan standar kompetensi dan kompetensi dasar yang harus dikuasai peserta. Materi BIPA bersumber dari buku BIPA Dashyat terbitan GSA Press. Perencanaan yang dibuat pengajar secara tertulis tersebut dituangkan dalam bentuk lesson plan. Selain materi, lesson plan juga berisi tujuan pembelajaran, metode pembelajaran, dan penilaian hasil belajar.

2. Proses pembelajaran BIPA di Pusat Bahasa Universitas Trisakti Jakarta dimulai dengan beberapa kegiatan sebagai berikut.

a. Kegiatan mengawali pembelajaran dengan menyampaikan salam, mengecek kehadiran peserta, menyampaikan tujuan pembelajaran, dan melakukan apersepsi.

b. Pengajar BIPA pada tingkat pemula mengelola proses belajar mengajar dengan cara menyampaikan materi kepada peserta dengan menggunakan metode pembelajaran kooperatif dengan menggunakan model picture and picture.

c. Pengajar mengakhiri pembelajaran dengan menyimpulkan materi, memberikan evaluasi dan pesan budaya kepada para peserta BIPA.

3. Penilaian hasil belajar BIPA dilakukan dengan teknik tes, baik tes tertulis maupun tes lisan.

Komik tidak hanya bacaan lucu, tetapi juga sebagai metode logis yang digunakan. Dengan menggunakan komik, pengajar dapat melatih hampir semua kompetensi. Ada banyak lagi keuntungan penggunaan komik. Peserta telah memberikan masukan yang baik setelah menggunakan komik dalam pembelajaran BIPA. Penerapan media komik di kelas BIPA ini menjadi nilai tambah yang ada di Program BIPA Universitas Trisakti Jakarta sendiri dibandingkan tempat lain. Peserta merasa nyaman dengan suasana kelas BIPA seperti itu. Peserta merasa tidak bosan karena aktivitas yang dilakukan di dalam kelas bersama pengajar lain. Oleh karena itu, saran bagi praktisi untuk terus mengembangkan dan mengintegrasikan media komik ke dalam materi pembelajaran BIPA. Semoga penelitian ini dapat menginspirasi para peneliti lainnya untuk melanjutkan penelitian serupa di bidang lainnya.

\section{Daftar Pustaka}

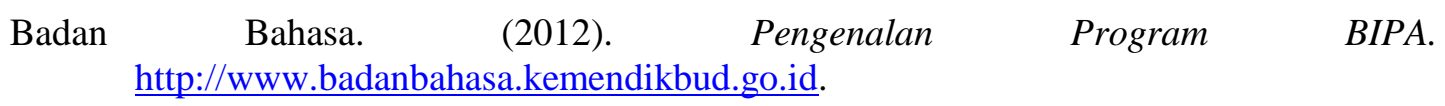

Brown, H. D. (1994). Teaching by Principles: an Interactive Approach to Language Pedagogy. Upper Saddle River. NJ: Prentice Hall Regents. 
Darmadi, H. (2009). Kemampuan Dasar Mengajar. Bandung: Alfabeta.

Eisner, W. (2002). Comics and Sequential Art. Florida: Poorhouse Press

Hurlock, E. B. (2000). Child Development. Jakarta: Erlangga.

Masdiono, T. (2001). 14 Jurus Membuat Komik. Jakarta: Creativ Media.

McCloud, S. (2001). Understanding Comic. Jakarta: Kepustakaan Populer Gramedia. (2008). Membuat Komik. Jakarta: PT Gramedia Pustaka Utama.

Oller, J. W. (1983). Story Writing Principles and ESL teaching. TESOL Quarterly, Vol. 17, No. 1, 39-53.

Poerwadarminta, W.J.S. (1982). Kamus Umum Bahasa Indonesia. Jakarta: PN Balai Pustaka.

Sudjana, N. dan R. Ahmad. (2001). Media Pengajaran. Bandung : CV Sinar Baru Bandung.

Sudjana, N. (2006). Penilaian Hasil Proses Belajar Mengajar. Bandung: Remaja Rosdakarya 